Acknowledgements. The assistance in the field by Else Dam and Ulla Hjorth Jakobsen is gratefully acknowledged. The program used to generate the symbol maps was implemented by $\mathrm{T}$. Tukiainen following principles developed by N. Gustavsson, Geological Survey of Finland.

\section{References}

Appel, P. W. U. 1984: Tungsten mineralisation in the Godthåb area, West Greenland. Rapp. Grønlands geol. Unders. 120, 51-54.

Appel, P. W. U. 1986: Strata bound scheelite in the Archean Malene supracrustal belt, West Greenland. Miner. Deposita 21, 207-215.

Appel, P. W. U. 1988: Scheelite in Malene supracrustals of the Ivisârtoq area, southern West Greenland. Rapp. Grønlands geol. Unders. 140.

Bridgwater, D., Keto, L., McGregor, V. R., \& Myers, J. S. 1976: Archaean gneiss complex of Greenland. In Escher, A. \& Watt, W. S. (edit.) Geology of Greenland, 18-75. Copenhagen: Geol. Surv. Greenland.

Escher, A. \& Pulvertaft. T. C. R. 1976: Rinkian mobile belt of West Greenland. In Escher, A. \& Watt, W. S. (edit.) Geology of Greenland, 104-119. Copenhagen: Geol. Surv. Greenland.

Garde, A. A. \& Marker, M. 1988: Corundum crystals with blue-red colour zoning near Kangerdluarssuk, Sukkertoppen district, West Greenland. Rapp. Grønlands geol. Unders. 140.

Garde, A. A., Jensen, S. B. \& Marker, M. 1987: Field work in 1986 in the Fiskefjord area, southern West Greenland. Rapp. Grønlands geol. Unders. 135, 36-42.
Kalsbeek, F. 1986: The tectonic framework of the Precambrian shield of Greenland. A review of new isotopic evidence. Rapp. Grønlands geol. Unders. 128, 55-64.

Kalsbeek, F., Taylor, P. N. \& Pidgeon, R. T. in press: Unreworked Archaean basement and Proterozoic supracrustal rocks from northeastern Disko Bugt, West Greenland: implications for the nature of Proterozoic mobile belts in Greenland. Can. J. Earth. Sci.

Knudsen, C., Appel, P. W. U., Hageskov, B. \& Skjernaa, L. 1988: Geological reconnaissance in the Precambrian basement of the Atâ area, central West Greenland. Rapp. Grønlands geol. Unders. 140.

Nutman, A. P. \& Friend, R. L. 1988: Evolution and assembly of Archaean terranes in the Kapisigdlit area, southern West Greenland. Rapp. Grønlands geol. Unders. 140.

Petersen, T. S. \& Sørensen, I. 1980: XRF 2: A Fortran programme for treatment of XRF data obtained with an absolutely calibrated XRF-spectrometer. Geol. Surv. Denmark, Yb. 1979, 125-138.

Steenfelt, A. 1987a: Geochemical mapping and prospecting in Greenland - a review of results and experience. J. geochem. Explor. 29, 183-205.

Steenfelt, A. 1987b: Geochemical trends in central and western North Greenland. Rapp. Grønlands geol. Unders. 133, 123-132.

Steenfelt, A. 1987c: Gold in the fine fraction of stream sediments from supracrustal sequences in West Greenland. Intern. GGU rep., 10 pp.

Steenfelt, A. \& Kunzendorf. H. 1979: Geochemical methods in uranium exploration in northern East Greenland. In Watterson, J. R. \& Theobald, P. K. (edit.) Geochemical exploration 1978, 429-442. Rexdale, Ontario: Association Exploration Geochemists.

\title{
Stream sediment sampling in the Atâ area, central West Greenland
}

\author{
Peter W. Uitterdijk Appel and Christian Knudsen
}

In 1982 scheelite was identified in stream sediments in the Nuuk/Godthåb area, about $600 \mathrm{~km}$ south of Atâ. Subsequently a regional stream-sediment programme was carried out in the Nuuk area from 1982 to 1987 as a result of which scheelite was found to be quite abundant in the $3800 \mathrm{~m} . \mathrm{y}$. old Isukasia supracrustal rocks as well as in the 3300 to $3000 \mathrm{~m} . \mathrm{y}$. old Malene supracrustal sequence (Appel, 1988). It.was also recognised that there is a close correlation between the number of scheelite grains and the gold content of the heavy mineral concentrates in the Nuuk area (Appel, 1988).
In the Atâ area (fig. 1) extensive outcrops of supracrustal rocks are found. In these supracrustals, which have been metamorphosed to greenschist and amphibolite facies, abundant sulphide-rich horizons are found, as well as sulphide-bearing breccia zones with appreciable gold contents (Knudsen et al., 1988).

During the 1987 field season geological reconnaissance mapping was carried out in two of the supracrustal areas and the gneiss-granite complex enclosing the supracrustal rocks -was investigated (Knudsen et al., 1988). A limited programme of stream-sediment sam- 
Fig. 1. Map of the Atâ area showing the sample sites with tungsten and gold contents indicated.

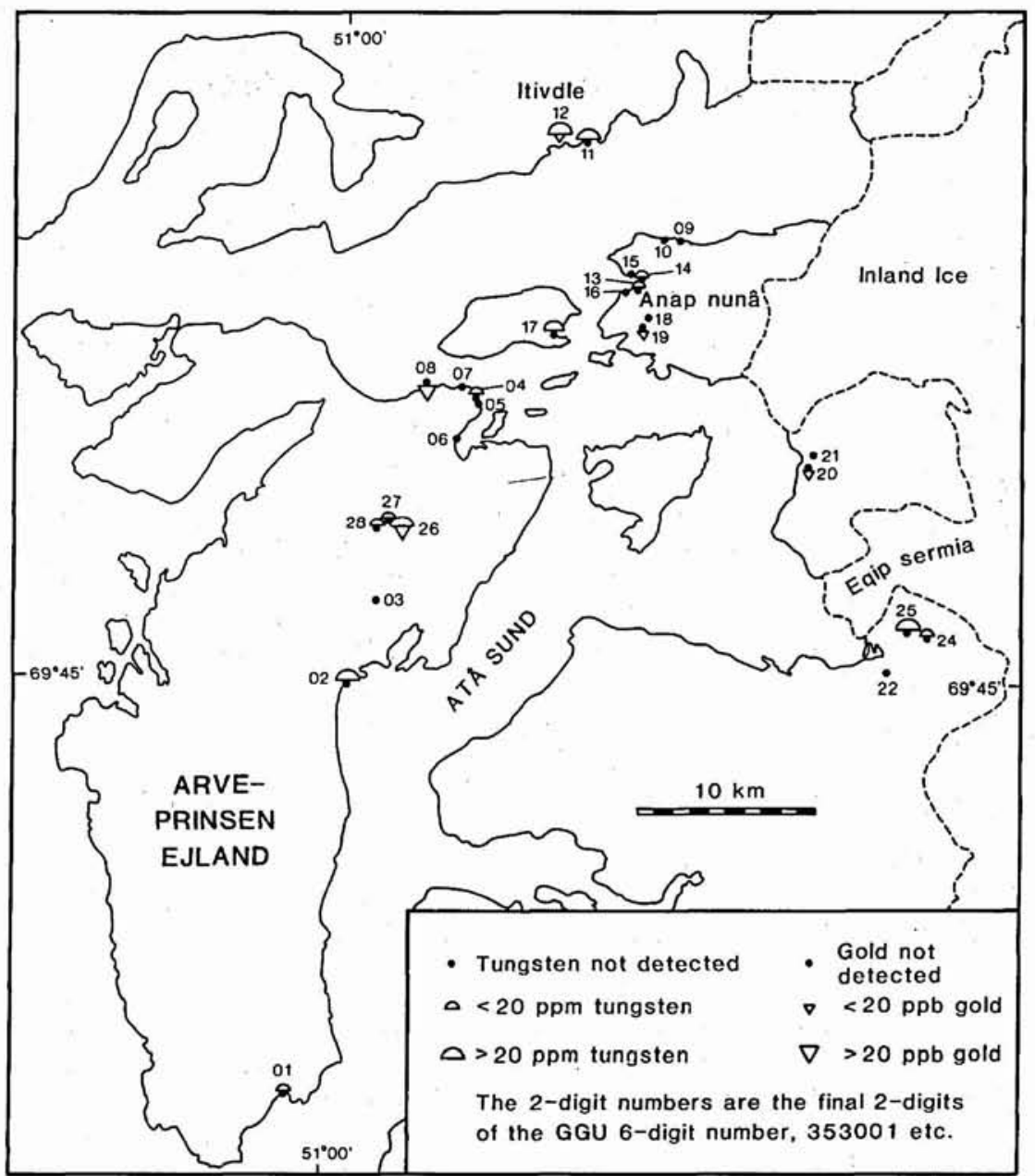

pling was carried out in the Atâ area, where streamsediment samples were collected in all the main streams draining the supracrustal rocks.

\section{Sampling programme}

The stream sediments collected in the Atâ area consisted of coarse gravel and sand collected in sieves which contain about $3 \mathrm{~kg}$ of sample material. The material was passed through a sieve with $1 \mathrm{~mm}$ holes. The fines were measured by volume and then concentrated by panning.

The heavy mineral concentrates were dried and the number of scheelite grains counted under ultra-violet light (except samples 353024 and 353025). The results are listed in Table 1.

\section{Results}

The heavy mineral concentrates were analysed by neutron activation by Bondar-Clegg, Ontario, Canada for gold and 33 other elements. The tungsten, gold and barium contents are listed in Table 1 . The analytical results for the following elements are available on request: $\mathrm{Na}, \mathrm{Sc}, \mathrm{Cr}, \mathrm{Fe}, \mathrm{Co}, \mathrm{Ni}, \mathrm{Zn}, \mathrm{As}, \mathrm{Se}, \mathrm{Br}, \mathrm{Rb}, \mathrm{Zr}$, Mo, Ag, Cd, Sn, Sb, Te, Cs, La, Ce, Sm, Eu, Tb, Yb, Lu, Hf, Ta, Ir, Th and U.

There is fairly good agreement between the observed number of scheelite grains and the tungsten content (Table 1), indicating that scheelite is the common tungsten-bearing mineral. There are, however, three notable exceptions, samples 3530001, 353008 and 353017. In samples 353001 and 353017 the tungsten mineral could be wolframite, whereas we cannot explain the discre- 
Table 1. Analyses of heavy mineral concentrates from stream sediments in the Atâ area

\begin{tabular}{|c|c|c|c|c|c|c|}
\hline & Scheelite/1 & W ppm & Au ppb & Ba ppm & Sieves & Vol \\
\hline $353001^{\bullet}$ & 0 & 16 & $<17$ & 450 & 3 & 0.2 \\
\hline 353002 & 10 & 65 & $<5$ & 320 & 3 & 0.5 \\
\hline $353003^{\circ}$ & 6 & $<7$ & $<5$ & 270 & 3 & 0.6 \\
\hline 353004 & 3 & 15 & $<5$ & 250 & 3 & 0.3 \\
\hline 353005 & 0 & $<6$ & $<5$ & 370 & 3 & 0.25 \\
\hline 353006 & 2 & $<5$ & $<5$ & 420 & 3 & 0.45 \\
\hline 353007 & 3 & $<2$ & $<5$ & 460 & 3 & 0.3 \\
\hline 353008 & 21 & $<9$ & 37 & 280 & 3 & 0.35 \\
\hline 353009 & 0 & $<7$ & $<5$ & $<100$ & 3 & 0.56 \\
\hline 353010 & 0 & $<6$ & $<5$ & 650 & 3 & 0.5 \\
\hline $353011^{*}$ & 30 & 120 & $<5$ & 4300 & 3 & 0.51 \\
\hline $353012^{*}$ & 64 & 81 & 16 & 240 & 3 & 0.26 \\
\hline 353013 & 1 & 7 & $<5$ & 260 & 60 & 5.21 \\
\hline 353014 & 0 & 13 & $<13$ & $<100$ & 4 & 0.2 \\
\hline 353015 & 0 & $<5$ & $<5$ & 500 & 4 & 0.42 \\
\hline 353016 & 0 & $<5$ & $<5$ & 430 & 4 & 0.09 \\
\hline 353017 & 0 & 24 & $<17$ & $<100$ & 4 & 0.35 \\
\hline 353018 & 0 & $<4$ & $<5$ & 730 & 3 & 0.1 \\
\hline 353019 & 0 & $<6$ & 19 & 320 & 3 & 0.2 \\
\hline 353020 & 0 & $<8$ & 15 & 1400 & 6 & 0.5 \\
\hline 353021 & 1 & $<5$ & $<5$ & 380 & 20 & 1.45 \\
\hline 353022 & 0 & $<6$ & $<5$ & $<100$ & 2 & 1.51 \\
\hline 353024 & & $<9$ & $<5$ & 440 & 3 & 0.2 \\
\hline $353025^{\circ}$ & 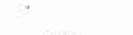 & 44 & $<5$ & 260 & 3 & 0.2 \\
\hline $353026^{\circ}$ & 32 & 93 & 32 & 290 & 6 & 0.6 \\
\hline $353027^{\circ}$ & 6 & 10 & $<5$ & 330 & 6 & 0.55 \\
\hline $353028^{*}$ & 0 & 7 & $<5$ & 440 & 3 & 0.35 \\
\hline
\end{tabular}

* Samples collected in amphibolite facies.

pancy between 21 grains of scheelite and less than 9 ppm tungsten in sample 353008 .

The gold contents in the heavy mineral concentrates are mostly too small to be detected. However, a few samples do contain interesting amounts of gold, and there is apparently some correlation between the gold content and the number of scheelite grains in the heavy mineral concentrates.

It should be noted that some stream sediments were collected in streams draining amphibolite facies metamorphosed supracrustal rocks; 353001 , 353003; 353011353012; 353025-353028.

\section{Conclusion}

This limited stream-sediment programme indicates that economically interesting tungsten occurrences may be found in the supracrustals of the Atâ area. Most of the scheelite apparently occurs in the supracrustal rocks which have undergone amphibolite facies metamorphism.

From this work and from the abundance of scheelite previously discovered in the supracrustal rocks further south (Appel, 1988) it is concluded that scheelite is probably more common in Precambrian supracrustal sequences than hitherto realised.

\section{References}

Appel, P. W. U. 1988: Heavy mineral concentrates from stream sediments collected in the Nuuk area, West Greenland during the period 1982-1987. Unpubl. intern. GGU rep.

Knudsen, C., Appel, P. W. U., Hageskov, B. \& Skjernaa, L. 1988: Geological reconnaissance in the Precambrian basement of the Atâ area, central West Greenland. Rapp. Grønlands geol. Unders. 140.

\title{
Reconnaissance aeromagnetic survey east of Disko Bugt, central West Greenland
}

\author{
Leif Thorning
}

The Geological Survey of Greenland plans a major aeromagnetic survey in the Disko Bugt region over the coming years. It has already been started with some introductory work in 1986 and 1987 (Knudsen et al., 1988). In this context, closed-file geophysical data were reviewed at GGU, and it soon became clear that good quality regional aeromagnetic data were lacking from the area and that the geological investigations would benefit from such data. Funds were not available for a systematic survey over the entire area, but in April 1987 a situation arose in which at least part of the area could be surveyed.

Due to the change of plans for the aeromagnetic surveying of the GICAS project, described by Thorning et al. (1988), it was possible to include one survey flight east of Disko Bugt. The measurements were made from the National Aeronautical Establishment aircraft (CFNRC), which is a well equipped Convair-580 with very good navigational capabilities and a 3-axis magnetic gradiometer. 